Print ISSN: 2234-3040 / Online ISSN 2234-3059 doi:10.13106/eajbm.2018.vol8.no4.5

\title{
Prospects and Challenges of Social Media Marketing: Study of Indian Management Institutes
}

\author{
Ravneet Singh Bhandari*, Sanjeev Bansal** \\ Received: April 18, 2018. Revised: June 20, 2018. Accepted: October 05, 2018
}

\section{Abstract}

Purpose - The research aimed to reveal real decisional behavioral of management institutes in India for social media marketing usage, and analyses of empirical elements of social media consumption pattern.

Research design, data, and methodology - The investigation was based around a research methodology using quantitative analysis with appropriate statistical techniques on random surveys of consumers, detailed exploratory and confirmatory factor analyses are applied to assess the empirical validity of the model and multiple regression employed using $R$ studio edition to validate the reliability of the developed models.

Results - A new conceptual framework is proposed - the management institutions decision model, providing a tool for effective and more focused decision-making strategies for developing better utilization techniques for social media. Management institutions have different requirements based upon objectives and resources available. The evidence suggests that the administrators need to be more aware of consumer indicators when targeting and designing social media marketing strategy.

Conclusions - The research was based on samples and not the entire population of target consumers, providing limitations. As an inferential statistical method was chosen, the results might be susceptible to inaccuracy. The model developed from different age users, thereby providing rich perspectives into social media usage pattern.

Keywords: Social Media Marketing, Management Institutes, Business Schools, Marketing Management, Digital Marketing.

JEL Classifications: M31, L86, D12.

\section{Introduction}

India has seen tremendous growth in the advanced management education division due to the interest for talented workforce and increasing service sector contribution enterprises. In advanced education, management training has seen a colossal development in the last decade. But managing these educational institutions more specifically management institutes, has become more complex because of changing environmental factors (Kwok \& Yu, 2013).

Digitalization has influenced and changed strategic functioning of organizations in India. Education sector, specifically, management education will see paradigm shifts in all areas of teaching, learning as well as marketing

* Corresponding Author, Research Scholar, Department of Marketing, Amity Business School, Amity University, Noida, India. E-mail: ravneetsinghbhandari@gmail.com.

** Dean FMS and Director, Amity Business School, Amity University, Noida, India.
(Kietzmann, Hermkens, McCarthy, \& Silvestre, 2011). The spurt in digitization with special reference to social media has raised genuine concerns over the kind of yield that would be produced with respect to management education in India. The significant concerns are educational modules, innovative work, issues related with going global and absence of very much prepared personnel(Kaplan \& Haenlein, 2010). Management institutions are confronting varied challenges, incorporating marketing of the establishments to students for affirmations and recruiters for placements, managing internal operations, recruitment and motivation of human resources(Hodis, Sriramachandramurthy, \& Sashittal, 2015). Management institutions are also subject to impulses of market forces- to stiff competition in terms demanding students and corporate. As India is considered as emerging digital economy including great number of social media users, there will be tough competition between these Management institutions for developing an effective as well functional social media marketing strategy (Gallaugher \& Ransbotham, 2010). The rationality of the study is to provide 
a constructive model for the academics, policy makers and management institutes to use social media as marketing tool.

Success is estimated thoroughly in the business world be it an product or service by means of volume of sales but in case social media marketing specifically for management institutions, literature review indicates that there are no authoritative, comprehensive and integrated study, has so far, been made to check prospects and challenges of social media marketing in management institutions like B-Schools (Durkin, McGowan, \& McKeown, 2013). Social media marketing for management institutions has been examined from different viewpoints i.e. subjective however not from the marketing tool point of view. Thusly, there is an expanding need to build up a complete estimation apparatus to quantify nature of social media marketing in management institutions in the present situation (Drury, 2008). The development of social networking as a marketing tool has changed how management institutes converse with their stakeholders and offer information about their brands(Culnan, McHugh, \& Zubilaga, 2010). No longer are stakeholders of management institutes are beneficiaries of promoting activities. Stakeholders today utilize social media to interface with organizations, which expands buyer engagement also, makes new kinds of connections amongst stakeholders and organizations. Social media has developed as a moderately ease path for institutes to produce new business and assemble associations with their clients(Araujo, Neijens, \& Vliegenthart, 2015). Social media is widespread and, subsequently, marketers can use these platforms not only for conveying messages just in case of conventional media, but projecting has turned into a multi way discussion. Marketers today need to go beyond just by making content to create campaigns and lock in customers on the web (Ahlers, 2012). Social media marketing empowers marketers in addition to making brand awareness, also create learning and online engagement on a progressing basis, and it is a source of market research that empowers marketers to update their strategies accordingly. Marketers need to audit what is in trend on via social media by carefully observing users, monitoring competitors and their environment and effectively responding to online activities(Ainin, Parveen, Moghavvemi, Jaafar, \& Shuib, 2015). Observing social media may help marketers to create more powerful marketing online networking content and enhance business tasks in the event that the data obtained is surveyed legitimately and followed up on inside a suitable time period. Understanding what the information assembled involves making choices about whether and how and when to react to online movement is fundamental to an effective social media marketing strategy which can be difficult to conduct without appropriate guidance(Tafesse, 2015). Firms regularly battle only build up a intimacy on social networking by paying for promoting via web-based networking media destinations or by making and updating pages on different social media platforms(Safko \& Brake, 2012). The vital introduction of associations may decide if administrators go past just anticipating data on the web(Plangger, 2012). They will gain from social media and modify their online methodologies in view of what they gain from online networking. Because of the many-sided quality required with dealing with an association's online networking showcasing methodologies, there is a requirement for a structure that blueprints the activities required to actualize every part of social media marketing. Past writing has tended to a large number of the segments of online networking showcasing administration, it may be, a system that considers the procedure with a key concentration has not been displayed(Kilgour, Sasse, \& Larke, 2015). Drawing from this writing, this article presents a new model to help directors of the management institutes in creating and utilizing web-based social networking as a promoting instrument. Likewise proposed is the manner by which the system will be utilized by organizations with various key introductions, as not all association might be capable or on the other hand ready to completely receive online networking(loanăs \& Stoica, 2014). Administration training has developed as a predominant monetary factor in India, particularly in India. The quantity of B-Schools is consistently expanding with the passage of driving private foundations from India and abroad. This development in administration instruction can be credited to the huge development saw in the state in segments, for example, data innovation, business process outsourcing, bio-innovation, retail, saving money and budgetary administrations, clinical look into and so on(Fotis, 2015).

There is uplifted rivalry among the current management institutes of India and more B-Schools are joining the raid (Private Universities, Autonomous B-Schools and Global Universities). Dealing with these Management institutes adequately in the changing situation calls for an arranged, sorted out approach, which can be given by broadly contemplating the factors affecting, the nature of the management institutes and tending to the necessities of the partners included(Fogel \& Nehmad, 2009). A model is required to quantify nature of social media marketing, thinking about the diverse partners and to conquer any hindrance between saw nature of administration (estimated regarding partner fulfillment) and genuine administration conveyance(Al Hasib, 2009). Brand building exercises could fill in as a key differential to recognize one B-School from another. The investigation proposes to recommend a model to gauge nature of Social media marketing (Akar \& Topcu, 2011). The literature reviewed by the author is limited in terms of parameters taken into consideration for estimating social media as a marketing tool, as few researchers have taken only the communication perspective of social media others taken the relationship management perspective only but in this research paper the author tried to combine all the elements associated with social media marketing. This paper is a attempt to provide as holistic and contemporary model for social media marketing. 


\section{Objectives of the study}

Consequently, the reason for this assessment is to explore the insights of social media marketing for management institutes. A number of empirical elements are taken into consideration. Social media marketing could conceivably have distinctive implications when utilizing each institute. This examination chose few sorts of social media marketing elements. Thus proposes and examine at four research questions, as follows:

- Which empirical elements motivate marketers to employ Social media marketing?

- In what way are the empirical elements for Social media marketing have implications with social media users?

\section{Review of Literature}

Social media marketing is an elusive and indistinct construct. It is a complex and difficult construct to measure in service sectors. The following features-characterize the education industry, as a services industry. Services are intangible- education cannot be seen, touched, heard or felt, before enrolling, it has to be experienced. This approach has been adapted to management education and the standard questions facilitate comparisons among B-schools (Felix, Rauschnabel, \& Hinsch, 2017). To make positive e-WOM, management institutes need to set up a campaign and manufacture can tent strategy on the web. Making awareness, drawing in new clients, and conveying the brand are common reasons management institutes connect with via social media marketing. Studies allude to Social media marketing as a bull horn used to send updates to generate online presence for users which may help to procure more clients(Pentina, Koh, \& Le, 2012).

Directors additionally need to comprehend that social media marketing has analytical aspect also, so how a users behave with its campaigns can be decoded using various analytical tools and users' online behavioral character and the idea of its associations with brand can be gained. Trust is developed amongst prospective students when management institutions develop connections over "good content offering," utilizing customized contact and bringing out engagement (Mozas-Moral, Bernal-Jurado, Medina-Viruel, \& Fernández-Uclés., 2016). The demonstration of attracting users is the thing that isolates an institute that as it were supports awareness from one that additionally energizes intelligence. Institutes ought to not fear taking part in discussions with clients as discussions help to fabricate community, hold users, build up new associations, and assemble connections(Koh \& Pentina, 2012). Two-way discussions help to customize the experience for users and provide feedback to firms. Prospected as well as existing students need to be heard and need institutes to hear them out and react(Grönroos, 1996). To make complaint redress and intuitiveness, firms must produce proper content. Finding the correct content to incorporate into messages is basic, as users may doubt marketer twisted data and excessively exaggerated posts may even lead users to quit following a business on the social media(Kao, Yang, Wu, \& Cheng, 2016).

Building up a web-based social networking interactions can be refined by prospecting users by means of messages as advertisements and posts that can incorporate content, photographs, recordings and illustrations (Jang, Olfman, Ko, Koh, \& Kim, 2008). Projected messages can promote occasions, entertainment, and knowledge offerings and offer internal view of the institute and news about the events of the institute, particularly on the off chance that they are convenient, point by point, and rich in data to guarantee user attention and comprehension recommend that varying media and visual substance make the most perceivability (Yuki, 2015). Utilizing the fitting language in the message is another imperative thought. Following an easygoing and more conversational tone may resound more with users. Institutes can utilize Social media marketing to draw inbound discourse and possibly pull in even latent spectators) either by reacting to purchaser started request and remarks or on the other hand by inciting this community engagement in any case(Malthouse, Haenlein, Skiera, Wege, \& Zhang, 2013). Marketers ought to make posts that intrigue users and attempt to support that enthusiasm by advertising impetuses for the individuals who take an interest, as content that is connecting with is more probable to be shared(Goh, Heng, \& Lin, 2013). To interact to users, firms often utilize reciprocity correspondence, easygoing tone, and personalization and must endeavor to be innovative crosswise over online networking stages. Content that makes social commitment (urges clients to connect with social media as opposed to simply "loving" it), creates passionate responses, is valuable and, instructive, and recounts a story drives sharing conduct(Michaelidou, Siamagka, \& Christodoulides, 2011). While informing is a critical aspect, but it isn't sufficient to simply post content; marketers additionally need to screen online action. It includes careful checking systems to always enhance, as the advertising condition changes habitually and firms must keep pace. They should figure out how to perceive and, obtain new learning(Jahn \& Kunz, 2012). Checking online networking regularly furnishes a firm with profitable redid essential research. A firm should screen the online networking scene to get aggressive insight about their clients, rivals, and the global scenarios and pick up a comprehension of how online networking can influence their own particular focused position (Lipsman, Mudd, Rich, \& Bruich, 2012). Monitoring can be accomplished by perusing user remarks and audits on online networking stages and web journals. This enables directors to get information about how users utilize their 
products. Tuning in to users and finding what they appreciate seeing and reacting to via web-based networking media can help a firm to make content that meets users' desires(Seyed-Ahmad \& Murphy, 2010). Understanding customers may give a firm an aggressive advantage, on the grounds that by checking it will find out about buyer needs and inclinations, Assessing can help supervisors recognize which clients to stay away from and which clients to develop connections with. Supervisors ought to likewise screen buyers to watch and find out about the connections, discoursed, and collaborations amongst firms and buyers in their industry to better evaluate when to react to buyer remarks(Schweidel \& Moe, 2014). Monitoring isn't adequate however: It is the way organizations utilize the data they get from observing that frequently has any kind of effect. Firms must be ready to process and survey the data to decide when and how to react. While numerous institutes screen their user and rivals, just the best ones assess the data and decide how to deal with the data. Not all data should be followed up on, and how web-based social networking action is estimated will decide how precisely the data produced advise leaders(Levy \& Gvili, 2015). One way to deal with surveying online networking movement is to assess volume measures (likes, retweets, shares, followers, pins, and so on.) that principally show the notoriety of a brand or post and might be more valuable if evaluated after me time. Real time behavior analysis can be useful, notwithstanding, when organizations screen posts all the time since this enables them to survey when their posted substance is best regarding purchaser reaction rates. For case, earlier research proposes that utilizing online networking to fortify electronic verbal advertising produces the most reactions on a specific day, however conjures numerous less reactions on other days(Pickton \& Broderick, 2001). Users check online networking out of gear times, fluctuating based on work timetable, socioeconomics, and psychographics, so a firm that screens effectively can survey when they should post, particularly for their objective market. Another way to deal with evaluating is to break down the content of approaching social media messages and user generated content to quantify conclusions, distinguish errors or issues, or notice chances to offer acclaim or consolation to clients or their representatives(Kumar, Bezawada, Rishika, Janakiraman, \& Kannan, 2016).

The overview of management institutes for social media marketing underscores the current need for researchers to expand on relation management on social media. One difficulty with engagement is the lack of definition of what relation management, Researchers define customer engagement more broadly as a psychological state with cognitive, emotional, and behavioral dimensions, this paper focuses on the actual participation or interaction of users with Management institutes' social media platforms as a definition of social media marketing.

\section{Research Methodology}

\subsection{Research design}

The author followed two methodological designs. First, exploratory research design which fits into the framework of random parameter models, for the purpose of identifying the elements associated to social media marketing. It is based on the initial assumption that the model parameters are a random variable that varies across individuals according to a given distribution. The second methodological design taken in this paper, involves the use of causal research design. The main purpose of this approach is that it explains the relationship between the identified variables to specify the underlying model. Multiple regressions used to develop the general model of mixtures with the twofold purpose of controlling for heterogeneity in the data and obtaining behaviorally distinct segments within the general pattern. This general model is the same as for the case in which the parameters are invariant between groups with the particularity that the latent variables, the observed variables and the measurement errors and, therefore, also, the parameters to be estimated, are segment-specific. The numbers of segments and parameter vectors, which can vary freely between segments, are set in accordance with the a priori known data about the issue under investigation and the goodness-of-fit between the models and the data.

\subsection{Sampling technique}

The target population for this study consisted of B-schools candidates from National Capital Region (NCR) of India. A sample of 500 social media users were selected using quota sampling method based on Social media adoption and usage data from a report conducted by Ministry of Information and Technology(India, 2017). The data were collected by means of an online questionnaire designed by author and administered by means of a technique known as computerassisted Web interviewing (CAWI). The data collection and database screening process provided 384 valid cases. Some descriptive statistics are given in Table 1. The average age of the interviewees is 22 years. In total, 56.80 per cent are males; 58.3 per cent have no children. Approximately,57 per cent are educated up to graduation level; 38 per cent have a post graduation level and the rest primary

\subsection{Measurement of the variables}

The online questionnaire is divided into different sections to address the various objectives of the study. The first section deals with aspects of Social media profile behaviour, such as frequency of log in, number of hours spent and device used shown in Table 1. The Table 2, which focuses on univariate analysis of the identified variables which are employed for Hypothetical testing. The variables with high mean values i.e. more than 2.5 from the scale of 1 to 5 
are considered as the positive implications of the Social media marketing. (departure from horizontal symmetry), and kurtosis tells you how tall and sharp the central peak is, relative to a standard bell curve. If skewness and kurtosis are positive, the data are positively skewed or skewed right, meaning that the right tail of the distribution is longer than the left. If skewness and kurtosis is negative, the data are negatively skewed or skewed left.

<Table 1> Social media usage and demographic profile of respondents $(\mathrm{N}=384)$

\begin{tabular}{|c|c|c|c|c|c|c|c|}
\hline Access & Male & Female & $\%$ & $18-20$ years & 20-22 years & 22-24 years & $\%$ \\
\hline $\begin{array}{c}\text { Mobile } \\
\text { Laptop \& PC }\end{array}$ & $\begin{array}{l}117 \\
106\end{array}$ & $\begin{array}{l}100 \\
111\end{array}$ & $\begin{array}{l}58 \% \\
52 \%\end{array}$ & $\begin{array}{l}67 \\
37\end{array}$ & $\begin{array}{l}87 \\
89\end{array}$ & $\begin{array}{l}43 \\
61\end{array}$ & $\begin{array}{l}52 \% \\
48 \%\end{array}$ \\
\hline \multicolumn{8}{|l|}{ Length of usage } \\
\hline $\begin{array}{c}>1 \text { year } \\
2 \text { years } \\
3 \text { years } \\
4 \text { years } \\
<5 \text { years }\end{array}$ & $\begin{array}{l}31 \\
36 \\
42 \\
40 \\
27\end{array}$ & $\begin{array}{l}46 \\
36 \\
44 \\
39 \\
49\end{array}$ & $\begin{array}{l}20 \% \\
19 \% \\
23 \% \\
21 \% \\
17 \%\end{array}$ & $\begin{array}{l}24 \\
21 \\
17 \\
30 \\
19\end{array}$ & $\begin{array}{l}28 \\
25 \\
22 \\
31 \\
23\end{array}$ & $\begin{array}{l}26 \\
29 \\
24 \\
31 \\
30\end{array}$ & $\begin{array}{l}21 \% \\
19 \% \\
16 \% \\
25 \% \\
19 \%\end{array}$ \\
\hline \multicolumn{8}{|l|}{ Log-on frequency } \\
\hline $\begin{array}{c}\text { Daily } \\
\text { Once in week } \\
\text { 2-4 weeks } \\
\text { Once in month }\end{array}$ & $\begin{array}{l}54 \\
40 \\
36 \\
12 \\
\end{array}$ & $\begin{array}{l}36 \\
22 \\
51 \\
49\end{array}$ & $\begin{array}{l}30 \% \\
21 \% \\
29 \% \\
20 \% \\
\end{array}$ & $\begin{array}{l}33 \\
25 \\
19 \\
12 \\
\end{array}$ & $\begin{array}{l}27 \\
19 \\
21 \\
15\end{array}$ & $\begin{array}{l}39 \\
28 \\
38 \\
24 \\
\end{array}$ & $\begin{array}{l}33 \% \\
24 \% \\
26 \% \\
17 \% \\
\end{array}$ \\
\hline \multicolumn{8}{|l|}{ Log-on duration } \\
\hline $\begin{array}{l}>1 \text { hour } \\
1-2 \text { hours } \\
2-3 \text { hours } \\
3-4 \text { hours } \\
<4 \text { hours }\end{array}$ & $\begin{array}{l}28 \\
39 \\
48 \\
40 \\
27\end{array}$ & $\begin{array}{l}46 \\
36 \\
44 \\
33 \\
39\end{array}$ & $\begin{array}{l}19 \% \\
20 \% \\
25 \% \\
19 \% \\
17 \%\end{array}$ & $\begin{array}{l}28 \\
33 \\
25 \\
18 \\
16\end{array}$ & $\begin{array}{l}20 \\
25 \\
26 \\
21 \\
18\end{array}$ & $\begin{array}{l}30 \\
21 \\
34 \\
44 \\
30\end{array}$ & $\begin{array}{l}21 \% \\
20 \% \\
23 \% \\
21 \% \\
15 \%\end{array}$ \\
\hline
\end{tabular}

<Table 2> Descriptive statistics of identified variables

\begin{tabular}{|c|c|c|c|c|c|c|}
\hline Variables & Mean & Std Dev & Max & Min. & Skewness & Kurtosis \\
\hline Engagement & 2.7685460 & 1.5621515 & 5 & 1 & 0.5163976 & -1.4059114 \\
\hline Updates & 2.8902077 & 1.5725867 & 5 & 1 & 0.4319878 & -1.5341848 \\
\hline e-learning & 2.9080229 & 1.6239909 & 5 & 1 & 0.3004480 & -1.6286583 \\
\hline Referral behaviour & 3.2008902 & 1.3212658 & 5 & 1 & 1.2773849 & 0.3740315 \\
\hline Real time analysis & 2.3086053 & 1.5137318 & 5 & 1 & 1.0041360 & -0.5808235 \\
\hline Behavioral measures & 2.2523353 & 1.3510158 & 5 & 1 & 1.2668193 & 0.2915188 \\
\hline Time line services & 2.3560832 & 1.4197481 & 5 & 1 & 1.0098814 & -0.4315693 \\
\hline Alumni relationships & 2.8872404 & 1.0346887 & 5 & 1 & 1.0545506 & -0.0544143 \\
\hline Collaboration & 3.2077252 & 0.5811010 & 5 & 1 & 2.5980581 & 5.0645592 \\
\hline Trust & 2.6023739 & 1.5340560 & 5 & 1 & 0.6638017 & -1.1742650 \\
\hline Commitment & 2.2869436 & 1.3857508 & 5 & 1 & 1.2139107 & 0.0906895 \\
\hline Reciprocity & 2.9080229 & 1.1854128 & 5 & 1 & 1.6455954 & 1.8276837 \\
\hline Sentiment analysis & 3.3857567 & 1.2414609 & 5 & 1 & -0.0416839 & -1.6707497 \\
\hline Impressions & 3.6637333 & 1.5014241 & 5 & 1 & 0.5641120 & -1.2559521 \\
\hline Brand equity & 3.8389933 & 1.2978444 & 5 & 1 & 0.9974832 & -0.9416926 \\
\hline e-Loyalty & 3.4356787 & 1.3456678 & 5 & 1 & 0.4564677 & 0.5678299 \\
\hline Brand awareness & 2.3086053 & 1.6239909 & 5 & 1 & 1.0041360 & -1.5341848 \\
\hline Content strategy & 2.2523353 & 1.3212658 & 5 & 1 & 1.2668193 & -1.6286583 \\
\hline Online presence & 2.3560832 & 1.5137318 & 5 & 1 & 1.0098814 & 0.3740315 \\
\hline e-WOM & 2.8902077 & 1.3510158 & 5 & 1 & 1.0545506 & -0.5808235 \\
\hline Media sharing & 2.9080229 & 1.4197481 & 5 & 1 & 2.5980581 & 0.2915188 \\
\hline Online reputation management & 3.2008902 & 1.0346887 & 5 & 1 & 0.6638017 & -0.4315693 \\
\hline Intimacy & 2.4086054 & 0.3811010 & 5 & 1 & 0.2039007 & -1.1544146 \\
\hline Lead management & 3.8873404 & 1.3212638 & 5 & 1 & 2.5980580 & -1.5818235 \\
\hline Campaigning & 4.3077353 & 1.3137318 & 5 & 1 & 0.6638007 & 1.2915188 \\
\hline Community management & 3.6034749 & 1.3310138 & 5 & 1 & 0.2039007 & -1.4315693 \\
\hline Data migration & 3.3869446 & 1.4197481 & 5 & 1 & 0.6455954 & -1.1544143 \\
\hline Feedback & 3.9080339 & 1.0346887 & 5 & 1 & -0.0406839 & 5.1645592 \\
\hline Emotion analysis & 3.4857567 & 0.3811010 & 5 & 1 & 0.5640020 & -1.1742651 \\
\hline Complaint redress & 3.6637333 & 1.3340360 & 5 & 1 & 0.9974832 & 1.1916895 \\
\hline Prospecting & 3.8389933 & 1.3837308 & 5 & 1 & 0.4564677 & 1.8276837 \\
\hline Brand monitoring & 2.4456787 & 1.1834128 & 5 & 1 & 0.0040360 & -1.6717497 \\
\hline Competition research & 2.4086054 & 1.2414609 & 5 & 1 & 0.2668093 & -1.2559521 \\
\hline Attitudinal measures & 2.2524454 & 1.3014241 & 5 & 1 & 0.0098804 & -1.9416926 \\
\hline Interactions & 2.4560842 & 1.2978444 & 5 & 1 & 0.0545506 & 1.5678299 \\
\hline Reviews & 2.8902077 & 1.3436678 & 5 & 1 & 2.598058 & -1.5341848 \\
\hline
\end{tabular}


$<$ Table 3> Confirmatory Factor Analysis

\begin{tabular}{|c|c|c|c|c|c|c|}
\hline Factors & Number of Items & $\begin{array}{l}\text { Scale Examples* } \\
\end{array}$ & Reliability $(\alpha)$ & Factor Loadings & Eigen Value & $\%$ Variance \\
\hline $\begin{array}{l}\text { Relationship } \\
\text { Management }\end{array}$ & \begin{tabular}{|l|}
11 \\
\end{tabular} & $\begin{array}{l}\text { Commitment, Trust, Intimacy, Reciprocity, Community } \\
\text { management, Media sharing, Lead management, } \\
\text { Timeline, Alumni relations, Data migration }\end{array}$ & 0.82 & $0.78-0.90$ & 4.303 & 0.3193 \\
\hline Projecting & 9 & $\begin{array}{l}\text { Brand awareness, e-WOM, Online presence, Content } \\
\text { strategy, Campaigning, Online reputation } \\
\text { management, Impressions, } \\
\text { e-Loyalty, Brand equity }\end{array}$ & 0.74 & $0.74-0.85$ & 3.754 & 0.2135 \\
\hline Communication & 8 & $\begin{array}{l}\text { Engagement, Feedback, Reviews, Complaint redress, } \\
\text { Prospecting, Interactions, e-Learning, Updates }\end{array}$ & 0.77 & $0.71-0.77$ & 2.174 & 0.1231 \\
\hline Monitoring & 8 & $\begin{array}{l}\text { Brand monitoring, Attitudinal measures, Competition } \\
\text { research, Referral behaviour, Real time analysis, } \\
\text { Behavioral measures, Sentiment analysis, Emotion } \\
\text { analysis }\end{array}$ & 0.73 & $0.74-0.88$ & 1.044 & 0.1192 \\
\hline
\end{tabular}

In the analysis of the data gathered from the questionnaire, SAS University edition used for statistical analysis. Cronbach alpha's a test was implemented for the reliability test of the scale, and it was calculated that Cronbach alpha $=0.673$. This value calculated shows that the scale is highly reliable. In order to facilitate understanding and interpretation of the relationship among a wide range of parameters stated in the questionnaire that are thought to have relations, and in order to reduce the amount to a more basic element, a factor analysis has been used. For the factor analysis feasibility test of data, the Kaiser-MeyerOlkin(KMO) test and the Bartlett test have been implemented. The value of the Bartlett test is 6,544.261. This value is $p=.000<.05$, so the result of the Bartlett test is significant. The value of the $\mathrm{KMO}$ test is calculated as 0.862. Therefore, there are high correlations among the parameters. In other words, the set of data is appropriate for factor analysis. In factor analysis, the "Varimax method" has been implemented, and four factors have been found. These four factors are 77.514 percent of the total variance as shown in Table 3.

\section{Hypothesis}

The motivation behind this exploration is to research the implications of the Social media marketing with respect to management education scenario. With acquaintance of the literature review and results of factor analysis the elements of Social media marketing had been arranged into 4 fundamental measurements:

$<$ H1 $>$ Greater the implication of Social media marketing, the better relationship management provided to the users.

$<\mathrm{H} 2>$ Greater the implication of Social media marketing, the better communication facilities provided to the users.
$<$ H3> Greater the implication of Social media marketing, the better monitoring management provided to the marketers

$<$ H4> Greater the implication of Social media marketing, the better projection management provided to the marketers.

\subsection{Proposed Framework}

A gap from the literature review suggests that there is a lack of focus on the prospects and challenges for Management institutes to adopt social media marketing. The literature states a limitation in research on social media marketing strategy frameworks for B-schools use and the evaluation of social media platform. The merging of social media strategy frameworks in Figure1, addresses their independent elements of Social media marketing. The framework considered the readiness of the Management institutes to adopt social media and how it is used in specific business context.

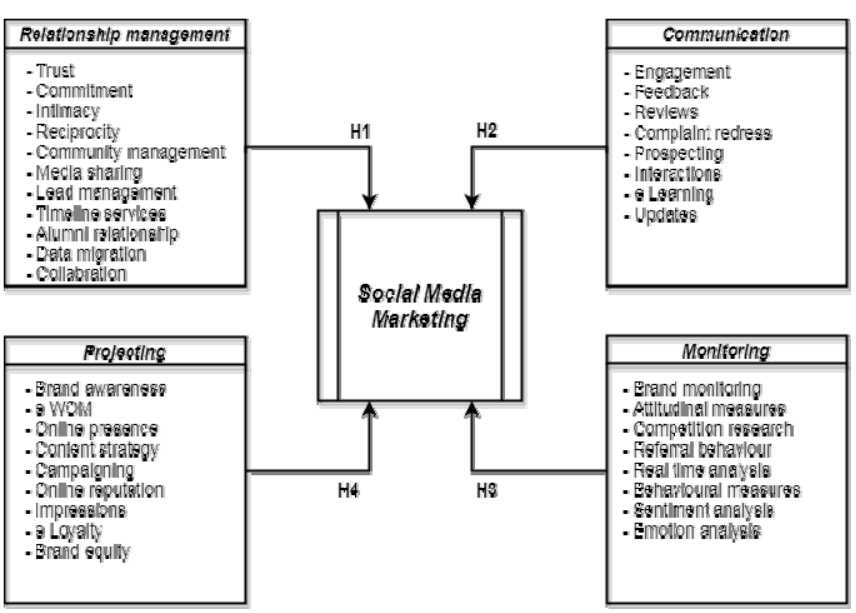

<Figure 1> Proposed conceptual model for the study 


\section{Hypothetical testing and Findings}

The hypothesized relationships were tested using multiple regression analysis, 4 models were shaped by the author where independent variables which were entered into the equation using "Forward selection" method" which were established from literature review. Following are the models testing hypothesis:

\subsection{H1: Model}

The hypothesized model for relationship management and social media marketing is represented in Table 4 , the $p$ values in the table is less than $0.0001, F$ value (23.69) and Adjusted R. sq. (0.4869) which is acceptable, therefore all the estimated coefficients are statistically significant $<$ Table $4>)$.

\subsection{H2: Model 2}

The hypothesized model for projecting factors and social media marketing is represented in Table 5 , the $p$ values in the table is less than $0.0001, \mathrm{~F}$ value (23.51) and Adjusted R. sq. (0.4234) which is acceptable, therefore all the estimated coefficients are statistically significant $(<$ Table $5>$ ).

<Table 4> Results for Relationship management and Social media marketing

\begin{tabular}{|c|c|c|c|c|c|}
\hline Variable & DF & Parameter Estimate & Standard Error & t Value & $\operatorname{Pr}>|t|$ \\
\hline Intercept & 1 & 1.44805 & 0.39727 & 3.65 & 0.0003 \\
\hline Commitment & 1 & -0.57522 & 0.09293 & -6.19 & $<.0001$ \\
\hline Trust & 1 & -0.01890 & 0.12204 & -0.15 & 0.0770 \\
\hline Intimacy & 1 & -0.01823 & 0.06266 & -0.29 & 0.7613 \\
\hline Reciprocity & 1 & 0.38823 & 0.08940 & 4.34 & $<.0001$ \\
\hline Community management & 1 & 0.60040 & 0.05759 & 10.43 & $<.0001$ \\
\hline Media sharing & 1 & -0.43391 & 0.16875 & -2.57 & 0.0106 \\
\hline Lead management & 1 & -0.01490 & 0.29727 & -8.19 & $<.0001$ \\
\hline Timeline & 1 & -0.01422 & 0.09292 & -0.15 & 0.0540 \\
\hline Alumni relations & 1 & 0.24422 & 0.12204 & -0.29 & 0.7453 \\
\hline Data migration & 1 & 0.40040 & 0.06266 & 3.33 & $<.0001$ \\
\hline Commitment & 1 & -0.42391 & 0.04940 & 10.33 & $<.0001$ \\
\hline \multicolumn{6}{|c|}{ Analysis of Variance } \\
\hline Source & & Sum of Squares & Mean Square & F Value & $\operatorname{Pr}>\mathrm{F}$ \\
\hline Model & 10 & 230.75308 & 21.07531 & 23.69 & $<.0001$ \\
\hline Error & 373 & 245.24692 & 0.84861 & Depd.Mean 2.000000 & R-Square 0.4948 \\
\hline Corrected Total & 383 & 476.00000 & Root MSE 0.92120 & Coeff. Var 46.05989 & Adj R-Sq 0.4869 \\
\hline
\end{tabular}

<Table 5> Results for Projection management and Social media marketing

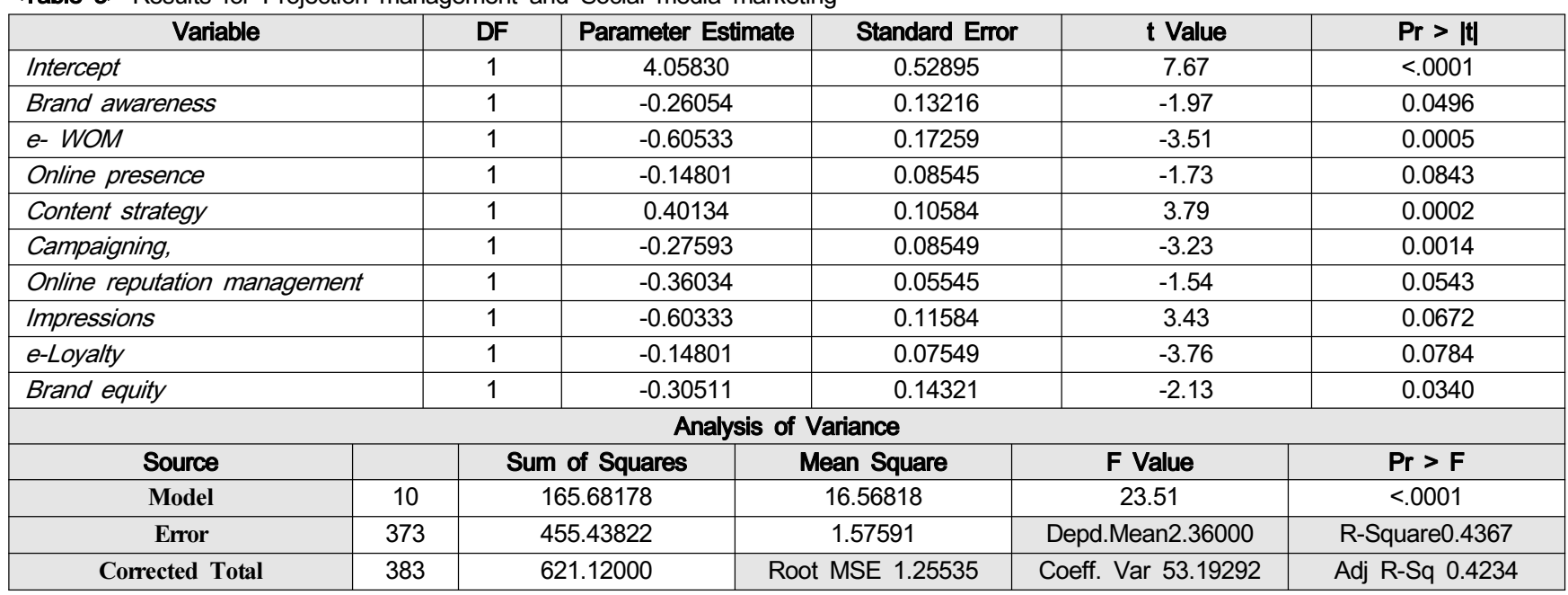


<Table 6> Results for Community management and Social media marketing

\begin{tabular}{|c|c|c|c|c|c|c|c|}
\hline \multicolumn{2}{|l|}{ Variable } & DF & \multicolumn{2}{|c|}{ Parameter Estimate } & Standard Error & t Value & $\operatorname{Pr}>|t|$ \\
\hline Intercept & Intercept & 1 & \multicolumn{2}{|c|}{0.11503} & 0.66441 & -0.17 & 0.8627 \\
\hline Engagement & & 1 & \multicolumn{2}{|l|}{0.53158} & 0.09296 & -5.72 & $<.0001$ \\
\hline Feedback & & 1 & \multicolumn{2}{|l|}{0.11629} & 0.12504 & -0.93 & 0.3531 \\
\hline Reviews & & 1 & \multicolumn{2}{|l|}{0.01588} & 0.06187 & -0.26 & 0.7976 \\
\hline Complaint redress & & 1 & \multicolumn{2}{|l|}{0.35809} & 0.08887 & 4.03 & $<.0001$ \\
\hline Prospecting & & 1 & \multicolumn{2}{|l|}{0.15429} & 0.65464 & -0.65 & 0.3231 \\
\hline Interactions & & 1 & \multicolumn{2}{|l|}{0.06888} & 0.54387 & -0.43 & 0.7686 \\
\hline e-Learning & & 1 & \multicolumn{2}{|l|}{0.37809} & 0.07887 & 4.23 & $<.0001$ \\
\hline Updates & & 1 & 0.58694 & & 0.05704 & 10.29 & $<.0001$ \\
\hline \multicolumn{8}{|c|}{ Analysis of Variance } \\
\hline Source & & \multicolumn{2}{|c|}{ Sum of Squares } & \multicolumn{2}{|c|}{ Mean Square } & F Value & $\operatorname{Pr}>\mathrm{F}$ \\
\hline Model & 11 & \multicolumn{2}{|c|}{237.77966} & \multicolumn{2}{|r|}{21.61633} & 26.13 & $<.0001$ \\
\hline Error & 373 & \multicolumn{2}{|c|}{238.22034} & \multicolumn{2}{|r|}{0.82715} & Depd.Mean2.000000 & R-Square0.4995 \\
\hline Corrected Total & 383 & \multicolumn{2}{|c|}{476.00000} & Roc & t MSE 0.90948 & Coeff. Var 45.47400 & Adj R-Sq 0.4804 \\
\hline
\end{tabular}

$<$ Table 7> Results for Monitoring management and Social media marketing

\begin{tabular}{|c|c|c|c|c|c|c|c|}
\hline \multicolumn{2}{|l|}{ Variable } & DF & \multicolumn{2}{|c|}{ Parameter Estimate } & Standard Error & t Value & $\operatorname{Pr}>|t|$ \\
\hline \multicolumn{2}{|l|}{ Intercept } & 1 & \multicolumn{2}{|c|}{1.91540} & 0.44141 & 4.34 & $<.0001$ \\
\hline \multicolumn{2}{|l|}{ Brand monitoring, } & 1 & \multicolumn{2}{|l|}{-0.08062} & 0.10451 & -0.77 & 0.4411 \\
\hline \multicolumn{2}{|l|}{ Attitudinal measures, } & 1 & \multicolumn{2}{|l|}{0.01658} & 0.63187 & -0.65 & $<.0001$ \\
\hline \multicolumn{2}{|l|}{ Competition research } & 1 & \multicolumn{2}{|l|}{0.45659} & 0.76887 & 4.77 & 0.4531 \\
\hline \multicolumn{2}{|l|}{ Referral behaviour } & 1 & \multicolumn{2}{|l|}{0.76729} & 0.32464 & -0.62 & $<.0001$ \\
\hline \multicolumn{2}{|l|}{ Real time analysis } & 1 & \multicolumn{2}{|l|}{0.04388} & 0.76387 & -0.65 & $<.0001$ \\
\hline \multicolumn{2}{|l|}{ Behavioral measures } & 1 & \multicolumn{2}{|l|}{-0.87818} & 0.23086 & -1.76 & $<.0001$ \\
\hline \multicolumn{2}{|l|}{ Sentiment analysis } & 1 & \multicolumn{2}{|l|}{-0.68757} & 0.76689 & -1.23 & 0.6562 \\
\hline \multicolumn{2}{|l|}{ Emotion analysis } & 1 & 0.32309 & & 0.87078 & 2.23 & 0.7876 \\
\hline \multicolumn{8}{|c|}{ Analysis of Variance } \\
\hline Source & & \multicolumn{2}{|c|}{ Sum of Squares } & \multicolumn{2}{|c|}{ Mean Square } & F Value & $\operatorname{Pr}>\mathrm{F}$ \\
\hline Model & 11 & \multicolumn{2}{|c|}{97.07316} & \multicolumn{2}{|c|}{8.82483} & 19.15 & $<.0001$ \\
\hline Error & 373 & \multicolumn{2}{|c|}{277.84350} & \multicolumn{2}{|r|}{0.96473} & Depd.Mean1.68333 & R-Square 0.4589 \\
\hline Corrected Total & 383 & \multicolumn{2}{|c|}{374.91667} & Ro & t MSE 0.98221 & Coeff. Var 58.34905 & Adj R-Sq 0.4206 \\
\hline
\end{tabular}

\subsection{H3: Model 3}

The hypothesized model for communication factors and social media marketing is represented in Table 6, the $p$ values in the table is less than $0.0001, F$ value (26.13) and Adjusted R. sq. (0.4804) which is acceptable, therefore all the estimated coefficients are statistically significant(<Table 6>).

\subsection{H4: Model 4}

The hypothesized model for monitoring factors and social media marketing is represented in Table 7 , the $p$ values in the table is less than $0.0001, F$ value (19.15) and Adjusted R. sq (0.4206) which is acceptable, therefore all the estimated coefficients are statistically significant(<Table $7>$ ).

\section{Discussion}

This paper introduces a conceptual structure that could be utilized by administrators of any Management institute or any other industry to enable them to deal with their social media marketing exercises. The framework and propositions provide an opportunity to examine a greater scope of social media marketing from a strategic perspective as well as a more tactical perspective. It provides an understanding for managers of the variety of issues related to the specific aspects of maintaining a firm's online presence based on firm scope, relations, projections, and governance. Apparently there are no ideal approaches to deal with managing Social media marketing, as the management institutes needs to choose which way it needs to take strategic decisions. For instance, an independent firm might not have time or assets to interface with various partners and subsequently may turn into a failure as a matter of course. The limited knowledge they have may restrict them from participating seeing someone or from checking or carefully evaluating data via social media. Anticipating data via social media might be the main concern that they can indulge. Be that as it may, fundamentally evaluating what a business does and how it can carefully enhance its Social media marketing is fundamental concern today, and this article proposes a model that could be utilized as a part of such an undertaking. 
Each measurement of the structure distinguishes activities that administrators in management institutes (with various degrees of communication, relationship management, and monitoring) attempt while actualizing social media use as an advertising technique.

It additionally features points of interest and issues that come from activities created by organizations with various key methodologies. The structure starts with distinguishing why a firm needs to utilize Social media, generally at first to disperse a message and later developing to collaborating and anticipating a institute's image to users. Once a firm distributes content, there is a need to screen responses to it and to screen the negative responses. Data gathered up from observing should be surveyed to decide when and how to make a reaction to it. At that point once data is surveyed and assessed, a choice about how or whether to react should be made. How a firm oversees every one of the diverse angles will shift contingent upon their relationship management, monitoring society, communication structure, and projecting administration.

The study presented in this paper reveals, unsurprisingly, that in several aspects, practice on social media marketing is lagging behind in terms of research. The numerous functions of social media are far from being fully exploited in actual management and communication. While research papers tend to deal with complex use cases of social media in relationship management and rather limits themselves to using social media as 'just another' media channel for distributing information. Examples of a more complex social media communication strategy are rare and mostly limited to management institutes participating in awareness campaigning: Several of the analyzed papers aim at considering the communication aspect only. It can be assumed that it will take time for these strategies to pervade actual prospective usage practice where flexible, accurate and reliable communication models and tools are used. As regards the academic publications used in the study, author also found a considerable number of contributions taking a rather critical standpoint towards social media marketing, in particular concerning legal and ethical aspects. Such critical discourse must be considered necessary, especially since delicate aspects such as security and surveillance are concerned. In addition, social media marketing strategies need to be fathomed in the public interest, closely considering societal developments and the potentially economically-driven practical implementation.

The study also revealed a lack of stronger prevalence of structural and quantitative research approaches among the analyzed academic publications with reference to Indian management education scenario compared to global ones. However, looking at the actual needs of institutes, micro level knowledge as well as evidence about individuals using social media in various situations can be useful. After all, both practical and theoretical approaches increasingly show a focus on stakeholders, aiming at enhancing users' participation and resilience for relationship management and communication. Future research can clearly contribute to improve and advance practical social media usage for management institutes by putting users into the other elements of analysis.

\section{Conclusion}

Contemplating Management institutes via social media systems uncovers what practices associate with business results and which kinds of conduct an association should urge to decidedly affect business. In this way, since communication is a perfect parameter for utilizing social media marketing due to an official structure, wideuser base, Institutes must decide instructions to quantify marketing on social media locales to decide whether it is a significant utilize of resources. While a significant number of the examinations and in this paper concentrated on relationship management aspect prevalent in social media locales. These internet tools ought to likewise be estimated in view of their capacity to upgrade connections between users. The model exhibited here can be used to gauge collaborations on these social media destinations, which incorporate activities like sharing, following, or liking posts. social media marketing additionally enable marketers to take part in comparative sorts of collaborations. Be that as it may, researchers looking at these systems ought to submerge themselves in the texture of the analytical concerns to understand what different kinds of cooperation and utilization might exist there. Moreover, in view of the previously mentioned quantities of adherents on estimating the effects of social media marketing is complex; however it is important if project ingresources will be utilized for these channels.

This paper has depicted how Social media marketing fits into the more extensive theory of relationship management, which is a feasible and productive methodology. Shifting the concentration to communication empowering one-time exchanges to building a discourse and two-way association with users can be encouraged by the utilization of social media marketing. In any case, if Social media marketing will be utilized to generate associations with users, as researchers have proposed they should, at that point they ought to be estimated by their capacity to do as such. Analyzing the writing on -monitoring estimation to the exploration on best practices for social media utilize, which recommend associations develop strategy to cooperate with users, gives a potential results to how associations should quantify social media use results. Utilizing engagement with management institutes' social media marketing accounts as a measure of behavioral engagement and deciding the effect of this engagement on relationship quality, as estimated by the depicted model, can give genuine appraisal information of social media as marketing tools. 


\section{References}

Ahlers, D. (2012). Local Web Search Examined, in Dirk Lewandowski (ed.) Web Search Engine Research (Library and Information Science, Volume 4), pp.47-7. United Kingdom: Emerald Group Publishing Limited.

Ainin, S., Parveen, F., Moghavvemi, S., Jaafar, N., \& Shuib, N. (2015). Factors influencing the use of social media by SMEs and its performance outcomes. Industrial Management and Data Systems, 115(3), 570588.

Ainin, S., Parveen, F., Moghavvemi, S., Jaafar, N., \& Shuib, N. (2015). Factors influencing the use of social media by SMEs and its performance outcomes. Industrial Management and Data Systems, 115(3), 570-588.

Akar, E., \& Topcu, B. (2011). An examination of the factors influencing consumers' attitudes toward social media marketing. Journal of Internet Commerce, 10(1), 35-67.

Al Hasib, A. (2009). Threats of online social networks. International Journal of Computer Science and Network Security, 9(11), 288-293.

Araujo, T., Neijens, P., \& Vliegenthart, R. (2015). What motivates consumers to re-tweet brand content? The impact of information, emotion and traceability on pass-along behavior. Journal of Advertising Research, 55(3), 284-295.

Culnan, M. J., McHugh, P., \& Zubilaga, I. (2010). How large U.S. companies can use twitterand other social media to gain business value. MIS Quarterly Executive, 9(4), 243-259.

Drury, G. (2008). Opinion piece: Social media: Should marketers engage and how can it be done effectively? Journal of Direct, Data and Digital Marketing Practice, 9 (3), 274-277.

Durkin, M., McGowan, P., \& McKeown, N. (2013). Exploring social media adoption in small to mediumsized enterprises in Ireland. Journal of Small Business and Enterprise Development, 20 (4), 716-734.

Felix, R., Rauschnabel, P., \& Hinsch, C. (2017). Elements of strategic social mediamarketing. Journal of Business Research, 70(1), 118-126.

Fogel, J., \& Nehmad, E. (2009). Internet social network communities: risk taking, trust, and privacy concerns. Computers in Human Behavior, 25(1), 153-160.

Fotis, J. N. (2015). THE USE OF SOCIAL MEDIA AND ITS IMPACTS ON CONSUMER BEHAVIOUR. London: BOURNEMOUTH UNIVERSITY.

Gallaugher, J., \& Ransbotham, S. (2010). Social media and customer dialog management at Starbucks. MIS Quarterly Executive, 9(4), 197-212.

Goh, K.-Y., Heng, C.-S., \& Lin, Z. (2013). Social media brand community and consumer behaviour: Quantifying the relative impact of user- and marketer-generated content. Information Systems Research, 24(1), 88-107.

Grönroos, C. (1996). Relationship marketing: Strategic and tactical implications. Management Decision, 34(3), 5-14.

Hodis, M. A., Sriramachandramurthy, R., \& Sashittal, H. (2015). Interact with me on my terms: A four segment Facebook engagement framework for marketers. Journal of Marketing Management, 31(11), 1255-1284.

Ioanăs, E., \& Stoica, I. (2014). Social Media and its Impact on Consumers Behavior. International Journal of Economic Practices and Theories, 4(2), 295-302.

Jahn, B., \& Kunz, W. (2012). How to transform consumers into fans of your brand. Journal of Service Management, 23(1), 344-361.

Jang, H., Olfman, L., Ko, I., Koh, J., \& Kim, K. (2008). The influence of on-line brand community characteristics on community commitment and brand loyalty. International Journal of ElectronicCommerce, 12(3), 57-80.

Kao, T.-Y., Yang, M.-H., Wu, J.-T. B., \& Cheng, Y.-Y. (2016). Co-creating value with consumers through social media. Journal of Services Marketing, 30(2), 141 $-151$.

Kaplan, A. M., \& Haenlein, M. (2010). Users of the world, unite! The challenges and opportunities of social media. Business Horizon, 53(1), 59-68.

Kietzmann, J. H., Hermkens, K., McCarthy, I., \& Silvestre, B. (2011). Social media? Get serious! Understanding the functional building blocks of social media. Business Horizons, 54(3), 241-251.

Kilgour, M., Sasse, S. L., \& Larke, R. (2015). The social media transformation process:curating content into strategy. Corporate Communications: An International Journal, 20 (3), 326-343.

Koh, A., \& Pentina, I. (2012). Exploring social media marketing strategies in SMEs. International Journal of Internet Marketing and Advertising, 74), 292-310.

Kumar, A., Bezawada, R., Rishika, R., Janakiraman, R., \& Kannan, P. K. (2016). From social to sale: The effects of firm-generated content in social media on customer behaviour. Journal of Marketing, 80(1), 7-25.

Kwok, L., \& Yu, B. (2013). Spreading social media messages on Facebook: An analysis of business-toconsumer communications. Cornell Hospitality Quarterly, 54(1), 84-94.

Levy, S., \& Gvili, Y. (2015). How credible is e-word of mouth across digital marketing channels. Journal of Advertising Research, 55(1), 95-109.

Lipsman, A., Mudd, G., Rich, M., \& Bruich, S. (2012). The power of like how brands reach(and influence) fans through social-media marketing. Journal of Advertising Research, 52(1), 40-52.

Malthouse, E. C., Haenlein, M., Skiera, B., Wege, E., \& Zhang, M. (2013). Managing customerrelationships in 
the social media era: Introducing the social CRM house. Journal of Interactive Marketing, 27(4), 270-280.

Michaelidou, N., Siamagka, N., \& Christodoulides, G. (2011). Usage, barriers and measurementof social media marketing: An exploratory investigation of small and medium B2Bbrands. Industrial Marketing Management, 4O(7), 1153-1159.

Mozas-Moral, A., Bernal-Jurado, E., Medina-Viruel, M., \& Fernández-Uclés., D. (2016). Factors for success in online social networks: An fsQCA approach. Journal of Business Research, 69(11), 5261-5664.

Pentina, I., Koh, A., \& Le, T. (2012). Adoption of social networks marketing by SMEs: Exploring the role of social influences and experience in technology acceptance. InternationaJournal of Internet Marketing and Advertising. InternationaJournal of Internet Marketing and Advertising, 7(1), 65-82.

Pickton, D., \& Broderick, A. (2001). Integrated marketing communications. New York: Pearson Education.
Plangger, K. (2012). The power of popularity: How the size of a virtual community adds to firm value. Journal of Public Affairs, 12(2), 145-153.

Safko, L., \& Brake, D. K. (2012). The Social Media Bible (3rd ed.). New Jersey: John Wiley \& Sons Inc.

Schweidel, D. A., \& Moe, W. (2014). Listening in on social media: A joint model ofsentiment and venue format choice. Journal of Marketing Research, 51(4), 387-402.

Seyed-Ahmad, S. F., \& Murphy, J. (2010). Social networking as a marketing tool: The case ofa small Australian company. Journal of Hospitality Marketing and Management, 19(7), 700-716.

Tafesse, W. (2015). Content strategies and audience response on Facebook brand pages. Marketing Intelligence \& Planning, 33(6), 927-943.

Yuki, T. (2015). What makes brands' social content shareable on Facebook. Journal of Research, 55(4), 458-470. 